Short Communication

\title{
Association study of folate-related enzymes (MTHFR, MTR, MTRR) genetic variants with non-obstructive male infertility in a Polish population
}

\author{
Mateusz Kurzawski ${ }^{1}$, Anna Wajda ${ }^{1}$, Damian Malinowski ${ }^{2}$, Anna Kazienko ${ }^{3}$, Rafal Kurzawa ${ }^{3}$ \\ and Marek Drozdzik ${ }^{1}$ \\ ${ }^{1}$ Department of Experimental and Clinical Pharmacology, Pomeranian Medical University, Szczecin, \\ Poland. \\ ${ }^{2}$ Department of Pharmacokinetics and Therapeutic Drug Monitoring, Pomeranian Medical University, \\ Szczecin, Poland. \\ ${ }^{3}$ Department of Reproductive Medicine and Gynecology, Pomeranian Medical University, Szczecin, Poland.
}

\begin{abstract}
Spermatogenesis is a process where an important contribution of genes involved in folate-mediated one-carbon metabolism is observed. The aim of the present study was to investigate the association between male infertility and the $\operatorname{MTHFR}(677 \mathrm{C}>\mathrm{T} ; 1298 \mathrm{~A}>\mathrm{C}), \operatorname{MTR}(2756 \mathrm{~A}>\mathrm{G})$ and MTRR $(66 \mathrm{~A}>\mathrm{G})$ polymorphisms in a Polish population. No significant differences in genotype or allele frequencies were detected between the groups of 284 infertile men and of 352 fertile controls. These results demonstrate that common polymorphisms in folate pathway genes are not major risk factors for non-obstructive male infertility in the Polish population.
\end{abstract}

Keywords: MTHFR, MTR, MTRR, polymorphism, infertility.

Received: June 12, 2014; Accepted: October 10, 2014.

Spermatogenesis is a multistep developmental process coordinated by sequential expression of various genes, with an important contribution of genes involved in folatemediated one-carbon metabolism. This pathway is mandatory for thymidylate and purine biosynthesis, thus providing substrates for DNA synthesis in rapidly dividing male germ cells. Via involvement in homocysteine metabolism, folates participate in DNA, RNA and histone methylation reactions, taking part in regulation of transcription. The key enzymes implicated in the above mentioned metabolic pathways are: 5,10-methylenetetrahydrofolate reductase (MTHFR), methionine synthase (MTR) and methionine synthase reductase (MTRR). It was found that polymorphisms defined within the coding sequences of these genes may affect metabolic pathways controlled by the enzymes.

Within the MTHFR gene, two functional single nucleotide polymorphisms (SNPs) were characterized. The MTHFR $677 \mathrm{C}>$ T variant (rs1801133) encodes a thermolabile protein variant with enzymatic activity decreased by $35 \%$ in heterozygotes and by $70 \%$ in the homozygous state. The MTHFR 1298A > C polymorphism (rs1801131) is associated with a $30 \%$ decrease in enzymatic activity. The MTHFR 677C > T and MTHFR 1298A > C SNPs were also

Send correspondence to Mateusz Kurzawski. Department of Experimental and Clinical Pharmacology, Pomeranian Medical University, Powstanców Wlkp. 72, 70-111 Szczecin, Poland. E-mail: mateusz.kurzawski@pum.edu.pl. shown to be associated with DNA hypomethylation (Weiner et al., 2014). In the MTR gene, an adenine to guanine transition at position 2756 (A > G, rs 1805087) results in substitution of aspartic acid with glycine in codon 919 of the protein and is related to alterations in the folate metabolic pathway. The Asp919Gly substitution in the MTR enzyme results in its higher activity, leading to more effective homocysteine remethylation and methionine production (Ravel et al., 2009). The MTRR gene includes a polymorphic locus MTRR 66A > G (rs1801394), which was shown to slightly reduce enzymatic activity, but was associated with decreased plasma homocysteine concentrations (Park et al., 2005).

The available information on associations of the above mentioned SNPs in MTHFR, MTR and MTRR genes with male infertility reported from various populations is not consistent, and mostly evaluate MTHFR gene. Most of the studies available are from Asian populations (Lee et al., 2006; A et al., 2007; Park et al., 2009), with some data from Caucasians: Italian (Stuppia et al., 2003), Dutch (Ebisch et al., 2003), Swedish (Murphy et al., 2011), French (Ravel et al., 2009; Montjean et al., 2011), German (Bezold et al., 2001), Spanish (Camprubi et al., 2013) and only one from an East European (i.e. Slavic) population, from Russia (Weiner et al., 2014). The results are still debatable, and the observed differences may not only depend on ethnic differences but also on environmental factors, i.e. folate intake, 
which in turn can influence DNA methylation and semen quality. The present study aimed at definition of associations of the common MTHFR, MTR and MTRR polymorphisms with male infertility in a Polish (i.e. Slavic) population.

The study was carried out in 284 consecutive, otherwise healthy male patients (aged 22-49 years, mean 32.7 \pm 4.7) without any chromosomal abnormalities, undergoing semen analysis due to infertility workup. The inclusion criteria were as follow: no children from current or previous relations with at least a year history of at least a year of regular (2-3 weekly), unprotected sexual activity without conception; female partners aged up to 35 years with regular menstrual bleedings and/or progesterone levels in the luteal phase of the cycle $>10 \mathrm{ng} / \mathrm{mL}$, normal transvaginal ultrasound examination, negative testing for Chlamydia trachomatis infection, without history of pelvic inflammatory disease or abdominal operations. Subjects were excluded from the study if semen analysis and clinical picture suggested obstructive azoospermia or testicular, epididymal, or accessory gland infection. Also, subjects with known systemic disease, BMI $\geq 30 \mathrm{~kg} / \mathrm{m}^{2}$, varicocele, history of mumps, testicular torsio or maldescence, trauma, as well as occupational hazards (exposure to solvents, pesticides, painting materials, heavy metals or radiation) were not taken into consideration.

The control group consisted of 352 healthy males (aged 21-56 years, mean $34.7 \pm 8.7$ ) recruited among consecutive men accompanying their female partners at term labor in the University Department of Feto-Maternal Medicine. Paternity was confirmed by women; however the possible paternal discrepancy was additionally checked based on blood group verification. Both the men undergoing infertility examination, as well as the fertile controls were Caucasians of Polish origin, recruited within the same geographical region. The study was approved by the local ethics committee and written informed consent was obtained from all subjects.

Genomic DNA was extracted from blood samples using GeneMATRIX Blood DNA Purification Kit (EURx, Poland). Pre-validated allelic discrimination TaqMan realtime PCR assays (Life Technologies, USA) were used for detection of the respective SNPs in MTHFR (rs1801131, rs1801133), MTR (rs1805087) and MTRR (rs1801394) genes. Amplification was performed in a 7500 Fast Real-Time PCR System with incorporated SDS software for SNP genotyping (Applied Biosystems, USA) using TaqMan GTXpress Master Mix (Life Technologies, USA). Fluorescence data was captured after 40 PCR cycles.

Allele and genotype frequencies were determined by direct counting of alleles. Concordance of genotype distribution with Hardy-Weinberg equilibrium was calculated using $\chi^{2}$ test. Genotype and allele frequencies between the study groups were compared by means of Fisher's exact test. The effect of each polymorphism was tested in both a dominant and recessive model. All genotypes were distributed in concordance with Hardy-Weinberg equilibrium, both in infertile patients and control subjects. No significant differences between the study groups were noted, neither in genotype distribution, nor in allele frequencies. All genotyping results are given in Table 1.

No significant impact of the studied polymorphisms on male infertility was revealed in the present study. The original concept of the impact of MTHFR variants on male reproduction and initial positive association of the thermolabile 677T variant with infertility came from the German study of Bezold et al. (2001), who reported significant overrepresentation of TT homozygotes among male patients seeking fertility evaluation compared with control group (18.8vs. 9.5\%). This preliminary report, without detailed characterization of neither male infertility nor control subjects, has been subsequently followed by several studies in Caucasian populations, i.e. Dutch (Ebisch et al., 2003), Italian (Stuppia et al., 2003), Swedish (Murphy et al., 2011), and Spanish (Camprubi et al., 2013). Contrary to the original report, the results of all aforementioned studies were negative. It should be noted that most of them simply lacked sufficient power to verify the existence of the investigated association, as numbers of participants were low (Table 2). Nonetheless negative association results were accompanied by findings on a potential relationship of MTHFR genotype and sperm counts, but only in some studies. Ravel et al. (2009) did not find any association between MTHFR $(677 \mathrm{C}>\mathrm{T}, 1298 \mathrm{~A}>\mathrm{C}$ and 215GA - rs2066472) genetic variants and sperm counts in French infertile men, which was later confirmed by Montjean et al. (2011) in a larger cohort of mixed ethnicity. Similarly, none of the genotypes was associated with neither standard seminogram parameters nor presence of sperm DNA hypomethylation (Camprubi et al., 2013). Finally, in the recent report from an East European population in Russia, Weiner et al. (2014) have observed the association of MTHFR genotype with azooospermia, but found no general impact of MTHFR 677C $>\mathrm{T}$ and MTHFR 1298A $>$ C polymorphisms on male infertility. Summarizing the observations from Caucasian studies, including the present Polish one, it seems that MTHFR 677C > T and MTHFR 1298A > C polymorphisms are not associated with male infertility.

In contrast to Caucasian studies, investigations on the association of MTHFR polymorphism with male infertility conducted in populations of non-European descent gave several positive results. Two large studies from Korea presented a significant association of the MTHFR $677 \mathrm{C}>\mathrm{T}$ (but not $1298 \mathrm{~A}>$ C) polymorphism with infertility (Park et al., 2005, Lee et al., 2006). Moreover, these observations were supported by a study in Chinese patients, where MTHFR 677T status was found to be a risk factor for male infertility (A $e t$ al., 2007). Data from Asian studies were also confirmed by other studies, including several reports revealing an impact of MTHFR $677 \mathrm{C}>\mathrm{T}$ polymorphism on infertility: from an 
Arabic population, i.e. Jordanians, by Mfady et al. (2014), a tive data for Indians, for both MTHFR 677C > T and Brazilian report on males of mixed ethnicity by Gava et al. $\quad$ MTHFR 1298A > C, were also reported (Dhillon et al., (2011), or by Gupta et al. (2011) from India. However, nega- 2007). Such impact of ethnic differences is also reflected in

Table 1 - Distribution of MTR, MTRR and Fluorescence data after 40 PCR cyclesMTHFR gene variants in infertile patients and control group.

\begin{tabular}{|c|c|c|c|c|c|c|}
\hline & \multicolumn{2}{|c|}{ Fertile $\mathrm{n}=352$} & \multicolumn{2}{|c|}{ Infertile $\mathrm{n}=284$} & \multirow[t]{2}{*}{$\mathrm{p}^{*}$} & \multirow[t]{2}{*}{ OR $(95 \% \mathrm{CI})$} \\
\hline & $\mathrm{n}$ & $\%$ & $\mathrm{n}$ & $\%$ & & \\
\hline \multicolumn{7}{|c|}{ MTR rs1805087 (2756A > G, Asp919Gly) } \\
\hline \multicolumn{7}{|l|}{ Genotype } \\
\hline AA & 218 & $61.9 \%$ & 178 & $62.7 \%$ & - & \\
\hline AG & 125 & $35.5 \%$ & 93 & $32.7 \%$ & 0.610 & $0.91(0.78-1.46)$ \\
\hline GG & 9 & $2.6 \%$ & 13 & $4.6 \%$ & 0.271 & $1.77(0.74-4.24)$ \\
\hline$(\mathrm{AG}+\mathrm{GG}) v s . \mathrm{AA}$ & 134 & $38.1 \%$ & 106 & $37.3 \%$ & 0.869 & $0.97(0.70-1.34)$ \\
\hline$(\mathrm{AA}+\mathrm{AG}) v s . \mathrm{GG}$ & 343 & $97.4 \%$ & 271 & $95.4 \%$ & 0.193 & $0.55(0.23-1.29)$ \\
\hline \multicolumn{7}{|l|}{ Allele } \\
\hline A & 561 & $79.7 \%$ & 449 & $79.0 \%$ & & \\
\hline G & 143 & $20.3 \%$ & 119 & $21.0 \%$ & 0.780 & \\
\hline \multicolumn{7}{|c|}{ MTRR rs 1801394 (66A > G, Ile22Met) } \\
\hline \multicolumn{7}{|c|}{ Genotype } \\
\hline AA & 70 & $19.9 \%$ & 51 & $18.0 \%$ & - & \\
\hline $\mathrm{AG}$ & 171 & $48.6 \%$ & 139 & $48.9 \%$ & 0.666 & $1.12(0.73-1.71)$ \\
\hline GG & 111 & $31.5 \%$ & 94 & $33.1 \%$ & 0.564 & $1.16(0.74-1.83)$ \\
\hline$(\mathrm{AG}+\mathrm{GG}) v s . \mathrm{AA}$ & 282 & $80.1 \%$ & 233 & $82.0 \%$ & 0.608 & $1.13(0.76-1.69)$ \\
\hline$(\mathrm{AA}+\mathrm{AG}) v s . \mathrm{GG}$ & 241 & $68.5 \%$ & 190 & $66.9 \%$ & 0.733 & $0.93(0.77-1.50)$ \\
\hline \multicolumn{7}{|l|}{ Allele } \\
\hline A & 311 & $44.2 \%$ & 241 & $42.4 \%$ & & \\
\hline G & 393 & $55.8 \%$ & 327 & $57.6 \%$ & 0.569 & \\
\hline \multicolumn{7}{|c|}{ MTHFR rs 1801133 (677C > T, Ala222Val) } \\
\hline \multicolumn{7}{|c|}{ Genotype } \\
\hline $\mathrm{CC}$ & 166 & $47.2 \%$ & 143 & $50.4 \%$ & - & \\
\hline $\mathrm{CT}$ & 150 & $42.6 \%$ & 113 & $39.8 \%$ & 0.448 & $0.87(0.63-1.21)$ \\
\hline TT & 36 & $10.2 \%$ & 28 & $9.9 \%$ & 0.783 & $0.90(0.52-1.55)$ \\
\hline$(\mathrm{CT}+\mathrm{TT})$ vs. $\mathrm{CC}$ & 186 & $52.8 \%$ & 141 & $49.6 \%$ & 0.426 & $0.880(0.64-1.20)$ \\
\hline$(\mathrm{CC}+\mathrm{CT})$ vs. TT & 316 & $89.8 \%$ & 256 & $90.1 \%$ & 0.895 & $1.04(0.62-4.75)$ \\
\hline \multicolumn{7}{|l|}{ Allele } \\
\hline $\mathrm{C}$ & 482 & $68.5 \%$ & 399 & $70.2 \%$ & & \\
\hline $\mathrm{T}$ & 222 & $31.5 \%$ & 169 & $29.8 \%$ & 0.502 & \\
\hline \multicolumn{7}{|c|}{ MTHFR rs1801131 (1298A > C, Glu429Ala) } \\
\hline \multicolumn{7}{|c|}{ Genotype } \\
\hline AA & 156 & $44.3 \%$ & 128 & $45.1 \%$ & - & \\
\hline $\mathrm{AC}$ & 156 & $44.3 \%$ & 130 & $45.8 \%$ & 0.933 & $1.02(0.73-1.41)$ \\
\hline $\mathrm{CC}$ & 40 & $11.4 \%$ & 26 & $9.2 \%$ & 0.413 & $0.79(0.46-1.37)$ \\
\hline$(\mathrm{AC}+\mathrm{CC}) v s . \mathrm{AA}$ & 196 & $55.7 \%$ & 156 & $54.9 \%$ & 0.873 & $0.97(0.71-1.32)$ \\
\hline$(\mathrm{AA}+\mathrm{AC}) v s . \mathrm{CC}$ & 312 & $88.6 \%$ & 258 & $90.8 \%$ & 0.433 & $1.27(0.76-2.14)$ \\
\hline \multicolumn{7}{|l|}{ Allele } \\
\hline A & 468 & $66.5 \%$ & 386 & $68.0 \%$ & & \\
\hline $\mathrm{C}$ & 236 & $33.5 \%$ & 182 & $32.0 \%$ & 0.589 & \\
\hline
\end{tabular}

*Calculated by means of Fisher's exact test. 
Table 2 - Previous studies on genes of folate-mediated one-carbon metabolism pathway in relation to male infertility.

\begin{tabular}{|c|c|c|c|}
\hline Genetic polymorphism studied & Association reported & Study population & Reference \\
\hline MTHFR $677 \mathrm{C}>\mathrm{T}$ & $\begin{array}{l}\text { MTHFR } 677 \mathrm{C}>\mathrm{T} \text { (TT homozygotes) with } \\
\text { infertility }\end{array}$ & $\begin{array}{l}255 \text { infertile men and } 200 \text { controls, eth- } \\
\text { nicity not given, Germany }\end{array}$ & Bezold et al., 2001 \\
\hline MTHFR $677 \mathrm{C}>\mathrm{T}$ & no association with infertility & $\begin{array}{l}93 \text { infertile and } 105 \text { controls, Italian } \\
\text { Caucasians }\end{array}$ & Stuppia et al., 2003 \\
\hline MTHFR $677 \mathrm{C}>\mathrm{T}$ & no association with subfertility & $\begin{array}{l}113 \text { fertile and } 77 \text { subfertile } \\
\text { males, Dutch Caucasians }\end{array}$ & Ebisch et al., 2003 \\
\hline $\begin{array}{l}20 \text { SNPs in } 12 \text { genes related to fo- } \\
\text { late, homocysteine and B12 metabo- } \\
\text { lism }\end{array}$ & $\begin{array}{l}\text { no association of folate-related gene } \\
\text { polymorphisms with infertility; PEMT } \\
\text { (phosphatidylethanolamine } \\
\text { N-methyltransferase) rs } 7946 \text { and CD } 320 \\
\text { (transcobalamin receptor) rs } 173665 \text { with } \\
\text { infertility }\end{array}$ & $\begin{array}{l}153 \text { infertile men and } 184 \text { controls, eth- } \\
\text { nicity not given, Sweden }\end{array}$ & Murphy et al., 2011 \\
\hline MTHFR $677 \mathrm{C}>\mathrm{T}$ & $\begin{array}{l}\text { no association with infertility or sperm } \\
\text { counts }\end{array}$ & $\begin{array}{l}107 \text { infertile men and } 25 \text { controls, eth- } \\
\text { nicity not given, Spain }\end{array}$ & Camprubi et al., 2013 \\
\hline $\begin{array}{l}\text { MTHFR } 677 \mathrm{C}>\mathrm{T}, 1298 \mathrm{~A}>\mathrm{C} ; \text { MTR } \\
2756 \mathrm{~A}>\mathrm{G} ; \text { MTRR 66A }>\mathrm{G} ; \text { SHMT1 } \\
\text { 1420C }>\mathrm{T} ; \text { MTHFD1 1958G }>\mathrm{A} ; \\
\text { CBS 844ins68 }\end{array}$ & $\begin{array}{l}\text { MTHFD } 1958 \mathrm{G}>\mathrm{A} \text { and } M T R 2756 \mathrm{~A}> \\
\mathrm{G} \text { with infertility (without correction for } \\
\text { multiple testing only); MTHFR } 677 \mathrm{C}>\mathrm{T} \\
\text { with azoospermia; }\end{array}$ & $\begin{array}{l}275 \text { infertile men and } 349 \text { controls, Rus- } \\
\text { sian Caucasians }\end{array}$ & Weiner et al., 2014 \\
\hline $\begin{array}{l}\text { MTHFR } 677 \mathrm{C}>\mathrm{T}, 1298 \mathrm{~A}> \\
\mathrm{C}, 215 \mathrm{GA} ; \text { MTRR } 66 \mathrm{~A}>\mathrm{G}, 524 \mathrm{C}> \\
\mathrm{T} ; C B S 919 G>A\end{array}$ & no association with reduced sperm counts & $\begin{array}{l}70 \text { azoospermia and } 182 \\
\text { oligozoospermia cases, } 114 \\
\text { normospermic controls, "French ethnic } \\
\text { origin" stated }\end{array}$ & Ravel et al., 2009 \\
\hline MTHFR $677 \mathrm{C}>\mathrm{T}, 1298 \mathrm{~A}>\mathrm{C}$ & MTHFR $677 \mathrm{C}>\mathrm{T}$ with infertility & $\begin{array}{l}373 \text { infertile men }+396 \text { controls, Ko- } \\
\text { rean Asians }\end{array}$ & Park et al., 2005 \\
\hline $\begin{array}{l}\text { MTHFR } 677 \mathrm{C}>\mathrm{T}, 1298 \mathrm{~A}>\mathrm{C} ; \text { MTR } \\
2756 \mathrm{~A}>\mathrm{G} ; \text { MTRR } 66 \mathrm{~A}>\mathrm{G}\end{array}$ & $\begin{array}{l}\text { MTHFR } 677 \mathrm{C}>\mathrm{T} \text { and } M T R R 66 \mathrm{~A}>\mathrm{G} \\
\text { with infertility; MTHFR } 677 \mathrm{C}>\mathrm{T} \text { and } \\
\text { MTR } 2756 \mathrm{~A}>\mathrm{G} \text { with azoospermia }\end{array}$ & $\begin{array}{l}360 \text { infertile men and } 325 \text { controls, Ko- } \\
\text { rean Asians }\end{array}$ & Lee et al., 2006 \\
\hline MTHFR $677 \mathrm{C}>\mathrm{T}$ & MTHFR $677 \mathrm{C}>\mathrm{T}$ with infertility & $\begin{array}{l}355 \text { infertile and } 252 \text { fertile Chinese } \\
\text { Asians }\end{array}$ & A et al., 2007 \\
\hline $\begin{array}{l}\text { MTHFR } 677 \mathrm{C}>\mathrm{T}, 1298 \mathrm{~A}> \\
\mathrm{C}, 215 \mathrm{GA} ; \text { MTRR } 66 \mathrm{~A}>\mathrm{G}, 524 \mathrm{C}>\mathrm{T}\end{array}$ & $\begin{array}{l}\text { MTHFR } 677 \mathrm{C}>\mathrm{T} \text { with } \\
\text { hyperhomocysteinemia; no association } \\
\text { with sperm counts }\end{array}$ & 522 men, mixed ethnic origin, France & Montjean et al. 2011 \\
\hline MTHFR $677 \mathrm{C}>\mathrm{T}, 1298 \mathrm{~A}>\mathrm{C}$ & $\begin{array}{l}\text { MTHFR } 677 \mathrm{C}>\mathrm{T} \text { with non-obstructive } \\
\text { azoospermia and severe oligozoospermia }\end{array}$ & $\begin{array}{l}156 \text { infertile men and } 233 \text { con- } \\
\text { trols, mixed ethnic origin, Brazil }\end{array}$ & Gava et al., 2011 \\
\hline $\begin{array}{l}\text { MTHFR } 677 \mathrm{C}>\mathrm{T}, 1298 \mathrm{~A}>\mathrm{C} \\
\text { DNMT3B } 46359 \mathrm{C}>\mathrm{T}\end{array}$ & no association with infertility & 179 infertile and 200 fertile men, India & Dhillon et al., 2007 \\
\hline MTHFR $677 \mathrm{C}>\mathrm{T}$ & $\begin{array}{l}\text { MTHFR } 677 \mathrm{C}>\mathrm{T} \text { with infertility, also } \\
\text { confirmed by meta-analysis of data from } \\
\text { available studies }\end{array}$ & 522 infertile and 315 controls, India & Gupta et al., 2011 \\
\hline $\begin{array}{l}\text { MTHFR } 677 \mathrm{C}>\mathrm{T}, 1298 \mathrm{~A}>\mathrm{C} \\
\text { MTRR } 66 \mathrm{~A}>\mathrm{G}\end{array}$ & MTHFR $677 \mathrm{C}>\mathrm{T}$ with infertility & $\begin{array}{l}150 \text { infertile and } 150 \text { controls, Arab Jor- } \\
\text { danian population }\end{array}$ & Mfady et al., 2014 \\
\hline MTHFR $677 \mathrm{C}>\mathrm{T}$ & $\begin{array}{l}\text { MTHFR } 677 \mathrm{C}>\mathrm{T} \text { with infertility in } \\
\text { Asians, but not I Caucasians }\end{array}$ & $\begin{array}{l}\text { metaanalysis of previously published } \\
\text { data }\end{array}$ & Wu et al, 2012 \\
\hline MTHFR $1298 \mathrm{~A}>\mathrm{C}$ & $\begin{array}{l}\text { MTHFR } 1298 \mathrm{~A}>\mathrm{C} \text { with infertility and } \\
\text { azoospermia (metaanalysis included only } \\
\text { one Caucasian study) }\end{array}$ & $\begin{array}{l}\text { metaanalysis of previously published } \\
\text { data }\end{array}$ & Shen et al., 2012 \\
\hline $\begin{array}{l}\text { MTHFR } 677 \mathrm{C}>\mathrm{T}, 1298 \mathrm{~A}>\mathrm{C} ; \text { MTR } \\
2756 \mathrm{~A}>\mathrm{G} ; \text { MTRR } 66 \mathrm{~A}>\mathrm{G}\end{array}$ & no association with infertility & $\begin{array}{l}284 \text { infertile and } 352 \text { fertile Polish Cau- } \\
\text { casians }\end{array}$ & present study \\
\hline
\end{tabular}

meta-analyses. A stratified analysis by Wu et al. (2012) showed that a significant association between MTHFR 677C $>\mathrm{T}$ polymorphism and male infertility was present only in Asians $(\mathrm{OR}=1.79$ for two copies of $\mathrm{T}$ allele and $\mathrm{OR}=1.42$ for $\mathrm{T}$ allele carriers), but not in Caucasians. A meta-analysis published by Shen et al. (2012) on the MTHFR 1298A > C variant gave similar results. However, the authors joined ge- netically distinct ethnic groups for the analysis (Korean and Indian) as "Asians", which does not seem to be fully justified. These meta-analyses also are in accordance with the negative observations from the present study in a Polish-Caucasian population.

There is scarce data on two other polymorphisms evaluated in the present study, i.e. MTR and MTRR. The 
MTR 2756A > G polymorphism was not associated with male infertility in the aforementioned Korean (Lee et al., 2006), Russian (Weiner et al., 2014), as well as the Swedish studies (Murphy et al., 2011). Our study does support these observations, as no impact of the MTR 2756A > G polymorphism on infertility in Polish males was found. However, the Korean study by Lee et al. (2006) found an association between MTR 2756GG genotype and an increased risk of azoospermia.

Similarly to the MTHFR polymorphism, the MTRR $66 \mathrm{~A}>\mathrm{G}$ polymorphism was found to impact male infertility in the Asian population. Lee et al. (2006) documented that the MTRR 66GG genotype promoted development of male infertility. Contrary to this, the Russian (Weiner et al., 2014) and French (Ravel et al., 2009) studies did not support the findings from the Korean population. Likewise, data from a Middle Eastern Arabic population demonstrated that the MTRR 66A > G genotype distribution was not different in fertile and infertile groups (Mfady et al., 2014). Our results from a non-Russian, Slavic population did not reveal an association between the MTRR $66 \mathrm{~A}>\mathrm{G}$ polymorphism and male infertility. In conclusion, the present study did not reveal a significant association of the MTHFR, MTR, MTRR gene polymorphisms with non-obstructive male infertility in a Polish population.

Nonetheless, the observed discrepancy between the results of studies conducted in different populations may result from both genetic determinants and environmental factors, including differences in folate consumption in different regions. Reduced folate levels can result from mutations in folate pathway genes, as well as insufficient dietary intake. Folate deficiency affects spermatogenesis by producing DNA hypomethylation and resultant gene expression changes, as well as inducing uracil misincorporation in the course of DNA synthesis, and thus errors in DNA repair, strand breakage and chromosomal abnormalities (Ravel et al., 2009). Deficiency of folates is also related with hyperhomocysteinemia, a risk factor for male infertility (Lee et al., 2006). Hyperhomocysteinemia may not only result from low folate consumption, but also from genetic variants in genes of the folate pathway (Bialecka et al., 2012). It was also demonstrated that folate treatment improved semen parameters, such as an increase in spermatozoa number and motility, as well as total normal sperm count.

\section{Acknowledgments}

The study was supported in part from National Science Centre grant (UMO-2011/01/B/NZ5/04235).

\section{References}

Zhou-Cun A, Yuan Y, Si-Zhong Z, Na L and Wei Z (2017) Single nucleotide polymorphism C677T in the methylenetetrahydrofolate reductase gene might be a genetic risk factor for infertility for Chinese men with azoospermia or severe oligozoospermia. Asian J Androl 9:57-62.

Bezold G, Lange M and Peter RU (2001) Homozygous methylenetetrahydrofolate reductase C677T mutation and male infertility. N Engl J Med 344:1172-1173.

Bialecka M, Kurzawski M, Roszmann A, Robowski P, Sitek EJ, Honczarenko K, Gorzkowska A, Budrewicz S, Mak M, Jarosz M, et al. (2012) Association of COMT, MTHFR, and SLC19A1(RFC-1) polymorphisms with homocysteine blood levels and cognitive impairment in Parkinson's disease. Pharmacogenet Genomics 22:716-724.

Camprubí C, Pladevall M, Grossmann M, Garrido N, Pons MC and Blanco JJ (2013) Lack of association of MTHFR rs1801133 polymorphism and CTCFL mutations with sperm methylation errors in infertile patients. J Assist Reprod Genet 30:1125-1131.

Dhillon VS, Shahid M and Husain SA (2007) Associations of MTHFR DNMT3b 4977 bp deletion in mtDNA and GSTM1 deletion, and aberrant $\mathrm{CpG}$ island hypermethylation of GSTM1 in non-obstructive infertility in Indian men. Mol Hum Reprod 13:213-222.

Ebisch IMW, Van Heerde WL, Thomas CMG, Van der Put N, Wong WY and Steegers-Theunissen RPM (2003) C677T methylenetetrahydrofolate reductase polymorphism interferes with the effects of folic acid and zinc sulfate on sperm concentration. Fertil Steril 80:1190-1194.

Gava MM, Chagas Ede O, Bianco B, Christofolini DM, Pompeo AC, Glina and Barbosa CP (2011) Methylenetetrahydrofolate reductase polymorphisms are related to male infertility in Brazilian men. Genet Test Mol Biomarkers 15:153-157.

Gupta N, Gupta S, Dama M, David A, Khanna G, Khanna A and Rajender S (2011) Strong association of $677 \mathrm{C}>\mathrm{T}$ substitution in the MTHFR gene with male infertility - A study on an Indian population and a meta-analysis. PLoS One 6:e22277.

Lee HC, Jeong YM, Lee SH, Cha KY, Song SH, Kim NK, Lee KW and Lee S (2006) Association study of four polymorphisms in three folate-related enzyme genes with non-obstructive male infertility. Hum Reprod 21:31623170.

Mfady DS, Sadiq MF, Khabour OF, Fararjeh AS, Abu-Awad A and Khader Y (2014) Associations of variants in MTHFR and MTRR genes with male infertility in the Jordanian population. Gene 536:40-44.

Montjean D, Benkhalifa M, Dessolle L, Cohen-Bacrie P, Belloc S, Siffroi JP, Ravel C, Bashamboo A and McElreavey K (2011) Polymorphisms in MTHFR and MTRR genes associated with blood plasma homocysteine concentration and sperm counts. Fertil Steril 95:635-640.

Murphy LE, Mills JL, Molloy AM, Qian C, Carter TC, Strevens H, Wide-Swensson D, Giwercman A and Levine RJ (2011) Folate and vitamin B12 in idiopathic male infertility. Asian J Androl 13:856-861.

Park JH, Lee HC, Jeong YM, Chung TG, Kim HJ, Kim NK, Lee SH and Lee S (2005) MTHFR C677T polymorphism associates with unexplained infertile male factors. J Assist Reprod Genet 22:361-368.

Ravel C, Chantot-Bastaraud S, Chalmey C, Barreiro L, AkninSeifer I, Pfeffer J, Berthaut I, Mathieu EE, Mandelbaum J, Siffroi JP, et al. (2009) Lack of association between genetic polymorphisms in enzymes associated with folate metabo- 
lism and unexplained reduced sperm counts. PLoS One 4:e6540.

Shen O, Liu R, Wu W, Yu L and Wang X (2012) Association of the methylenetetrahydrofolate reductase gene A1298C polymorphism with male infertility: A meta-analysis. Ann Hum Genet 76:25-32.

Stuppia L, Gatta V, Scarciolla O, Colosimo A, Guanciali-Franchi P, Calabrese G and Palka G. (2003) The methylenetethrahydrofolate reductase (MTHFR) C677T polymorphism and male infertility in Italy. J Endocrinol Invest 26:620-622.

Weiner AS, Boyarskikh UA, Voronina EN, Tupikin AE, Korolkova OV, Morozov IV and Filipenko ML (2014) Poly- morphisms in folate-metabolizing genes and risk of idiopathic male infertility: a study on a Russian population and a meta-analysis. Fertil Steril 101:87-94.

Wu W, Shen O, Qin Y, Lu J, Niu X, Zhou Z, Lu C, Xia Y, Wang S and Wang X (2012) Methylenetetrahydrofolate reductase C677T polymorphism and the risk of male infertility: A meta-analysis. Int JAndrol 35:18-24.

Associate Editor: Angela M. Vianna-Morgante

License information: This is an open-access article distributed under the terms of the Creative Commons Attribution License, which permits unrestricted use, distribution, and reproduction in any medium, provided the original work is properly cited. 